\title{
Theo-genetiese kodes van die APEHL, soos afgelei uit Efesiërs 4, beliggaam
}

\begin{abstract}
Author:
J. Christo Van der Merwe ${ }^{1}$ (I)

Affiliation:

${ }^{1}$ Reformed Theological

College, Faculty of Theology, University of Pretoria,

South Africa

Research Project Registration: Project Leader: A. Ungerer

Project Number: 82329542

\section{Description:}

Dr Van der Merwe is participating in the research project, 'Contextualized Reformed Theology in South Africa', directed by Dr Andre Ungerer of the Reformed Theological College, Faculty of Theology, University of Pretoria.
\end{abstract}

\section{Corresponding author:} Christo van der Merwe, christo.vandermerwe@up. ac.za

Dates:

Received: 01 June 2017

Accepted: 26 July 2017

Published: 29 Nov. 2017

How to cite this article: Van der Merwe, J.C., 2017

'Theo-genetiese kodes van die APEHL, soos afgelei uit Efesiërs 4, beliggaam', HTS Teologiese Studies/ Theological Studies 73(1), a4682. https://doi.org/ 10.4102/hts.v73i1.4682

\section{Copyright:}

(c) 2017. The Authors. Licensee: AOSIS. This work is licensed under the Creative Commons Attribution License.

\section{Read online:}

The focus of this article is on the incarnation of Jesus Christ, the Word become flesh, as a way of talking about and understanding mission and addresses at least two concerns in the contemporary debate about the missional church. Many missionary methods and strategies have contradicted both the teaching and actions of Jesus as he trained his disciples to continue his ministry. The message may have been the gospel, but the way the message was made known was often not congruent with the gospel. The attempt to interpret mission in terms of the incarnation of Jesus suggests that the earlier forms of mission strategies should be replaced by a theology and praxis rooted in and defined by the life and ministry of Jesus. Ephesians 4 provides the key to the theology and praxis by giving us a direct link backward into the ministry that infused and led the early church in the life and the ministry of Jesus.

\section{Die Woord het vlees geword}

Die inkarnasie van Jesus Christus (Joh 1:14), 'En die Woord het vlees geword en onder ons kom woon', gaan oor die inisiatief wat God geneem het om die gebroke en sondige skepping met Homself te versoen. Die Bybel getuig omvattend van God se missionale betrokkenheid by sy skepping, beginnende by Abraham, met as hoogtepunt die inkarnasie van Jesus, die Seun van God (Wright 2006:194 verv):

God the Father sent Jesus the Son as the Messiah, the Christ, the Annointed One, whose life, death, and resurrection are the epitome and turning point of God's mission to redeem humanity and the world. The Father and the Son sent the Holy Spirit to call and to empower the church to carry out its witness to this gracious good news. (Guder 1999:2)

\section{God se sending}

Bosch noem Karl Barth die eerste duidelike verteenwoordiger van 'n nuwe teologiese paradigma wat 'n radikale breuk was met die teologie van die Verligting. Barth se invloed op missionêre denke het 'n hoogtepunt bereik by die Willingen Konferensie van 1952:

It was here that the idea (not the exact term) missio Dei first surfaced clearly. Mission was understood as being from the nature of God. It was thus put in the context of the doctrine of the Trinity, not of ecclesiology or soteriology. The classical doctrine on the missio Dei as God the Father sending the Son, and God the Father and the Son sending the Spirit was expanded to include yet another 'movement': Father, Son and Holy Spirit sending the church into the world. (Bosch 1993:300)

Peterson (2013:84) verstaan die begrip missionaal ook op grond van die missio Dei as die 'essential nature and vocation of the church as God's called and sent people'. Missionale gemeentes bestaan ter wille van God se wêreld (Kirk 2000:52-55; Van Gelder 2007:30). Daarom moet elke geslag deur die Heilige Gees gelei word om nuwe maniere te vind 'to express their fellowship and mission (Ward 2002:1)'. Die vertrekpunt van die huidige missionale gesprek is dat God teenwoordig is en aktief besig is om in sy wêreld te werk. Dit bring 'n nuwe fokus op die identiteit, aard en wese van gemeentes mee, om gemeentes gevolglik doelbewus te begelei tot missionale selfverstaan (Rouse \& Van Gelder 2008:26).

'n Missionale kerk besef dat verandering altyd by 'n lewe in die Drie-Enige God begin. Niemandt (2013:25) vergelyk dit met 'n 'beweging of dans wat al meer en meer mense innooi om in pas met God te lewe en te dans (perichoresis)'. Tyra (2013) praat van 'n 'social Trinity' waarin God verstaan word as:

... a relational community of equality and mutuality within which the distinctive identity of each person of the Trinity is fully maintained as Father, Son and Spirit. There is a irreducible otherness within God in relation to each person of the Trinity. This deep interrelated communion of the three persons of the Trinity is often expressed by the word perichoresis, which refers to the mutual indwelling within the threefold 
nature of the Trinity. All three persons of the divine community indwell one another in a relation unity while maintaining their distinct identities. (p. 174)

Volgens Alan Hirsch (2006:15) het die Heilige Gees die vermoë om in pas met die Drie-Enige God te lewe in die inisiërende 'stamsel' (DNS) van die kerk ingebou, maar deur die eeue het dit verlore geraak omdat die hoë vlak van verbintenis aan die kerk se aanvanklike roeping nie lank volgehou is nie (sien ook Bosch 1993:50). Reeds op 'n vroeë stadium in die kerk se geskiedenis het Christene weer deel begin word van alles wat hulle van ander onderskei het. Oorlewing as religieuse groep eerder as verbondenheid aan 'n lewe in pas met God het toenemend weer hulle energie opgeëis. Dit het daartoe gelei dat die Jesusbeweging spoedig bloot ' $n$ nuwe geloof geword het, en onvermydelik het dit op sy beurt' $n$ nuwe rede vir verdeeldheid geword. Nou verweef hiermee het die kerk ook al meer as statiese instituut ontwikkel.

'n Instituut en 'n beweging verskil in vele opsigte: die een is konserwatief, die ander progressief; die een is min of meer passief, terwyl dit toegee aan invloede van buite, die ander is aktief, wat beïnvloed eerder as om beïnvloed te word; die een is gerig op die verlede, die ander is gerig op die toekoms; die een is angstig, die ander is bereid om risiko's te neem; die een bewaar grense, die ander steek grense oor (Bosch 1993:50).

Die verskille tussen 'n instituut en beweging is duidelik wanneer die Christengemeenskap in Jerusalem vergelyk word met dié in Antiogië in die veertigerjare van die eerste eeu (Wright 2006:191-193). Die gemeente van Antiogië se pioniersgees het aanleiding gegee tot " $n$ haastige inspeksie deur Jerusalem' (Bosch 1993:51). Die Jerusalem afvaardiging was nie soseer besorg oor sending nie maar eerder oor konsolidasie; nie genade nie maar wet; nie om grense oor te steek nie, maar om grense vas te stel; nie lewe nie maar dogma; nie beweging nie maar instituut.

Bogenoemde spanning het gelei tot die byeenroep van die eerste Apostoliese Sinode van 47-48 n.C. Volgens Lukas (Handelinge 15) en Paulus (Galasiërs 2) was die Sinode op daardie stadium ten gunste van die uitreik na heidene. Op die lang duur egter het dit geblyk dat die geneigdheid om as instituut te funksioneer, sterker was. Hierdie tendens het nie slegs in die Joods-Christelik gemeenskappe gemanifesteer nie, maar uiteindelik ook in die heidens-Christelike gemeenskappe. Op 'n vroeë stadium reeds was dit duidelik dat twee tipes geloofsgemeenskappe aan die ontwikkel was: die gevestigde statiese bediening van biskoppe (ouderlinge) en diakens, en die mobiele bediening van apostels, profete en evangeliste. Waar die gevestigde bediening al hoe meer as statiese instituut ontwikkel het, het die mobiele bediening die dinamika van 'n beweging bly behou. In die vroeë jare van Antiogië was 'n kreatiewe spanning tussen die twee tipes bedieninge wel aanduibaar. Op ander plekke, later ook in Antiogië, het die gemeentes egter uitsluitlik as institute ontwikkel wat al minder begaan was oor die wêreld buite die instituut se grense:
Soon they had to design rules for guaranteeing the decorum of their worship meetings (cf 1 Cor 11:2-23; 1 Tim 2:1-13), and for addressing criteria for the ideal clergyman and his wife (1 Tim 2:1-13), and for addressing cases of inhospitality to church emissaries and of hunger for power (3 Jn; cf Malherbe 1983:92-112). As time went by, intra-ecclesial issues and the stuggle for survival as a separate religious group consumed more and more of the energy of Christians. (Bosch 1993:51)

Die vroeë kerk het ook in 'n ander opsig missionaal gefaal. Hulle het ook nie meer daarin geslaag om die Jode te bly bereik soos aan die begin nie. In die veertigerjare van die eerste eeu het die kerk stelselmatig verander van 'n beweging wat gerig was op Jode én heidene, na 'n beweging uitsluitlik gerig op die heidene.

\section{Belangrike keerpunt}

Januarie 313 n.C. word gesien as keerpunt in die geskiedenis van die kerk. Tot op daardie stadium is Christene in die Romeinse Ryk erg benadeel. Selfs al is hulle nie aktief vervolg nie, is daar op verskeie terreine teen Christene gediskrimineer; hulle is gewantrou en verdink van dislojaliteit teenoor die staat en in sommige gevalle selfs as polities gevaarlik geag.

Die Edik van Milaan (313 n.C.) het die situasie radikaal verander. Dit het meegebring dat die kerk vasgevang geraak het in ' $n$ wyse van bestaan waarna algemeen verwys is as Christenheid. Dié term word gebruik om 'n tydvak aan te dui wat in die vierde eeu begin het toe Konstantyn die Christelike godsdiens tot wettige godsdiens verklaar het en Teodosius dit tot staatsgodsdiens verhef het (Niemandt 2007:13).

Die gevolg was dat kerk en kultuur so verweef geraak het dat die een mettertyd moeilik van die ander te onderskei was (Robinson 2003:15). Dit is dus vanselfsprekend dat Christenheid 'n bepalende invloed sou uitoefen op die kerk (Niemandt 2007:14-15).

Die kerk van die 21ste eeu is as gevolg van indringende paradigmaskuiwe gekonfronteer met nuwe uitdagings van geweldige omvang. Niemandt (2007) haal Hauerwas aan:

Iewers tussen 1960 en 1970 het 'n onbekookte wêreld tot 'n einde gekom en het 'n vars, nuwe wêreld begin. Al het almal nog nie die nuus gehoor nie, is dit die reine waarheid - 'n moeë ou wêreld het op sy einde gekom en 'n opwindende nuwe wêreld wag om raakgesien te word. (bl. 11)

Die uitdagings van die 21ste eeu verskil radikaal van dié van vroeëre eras. Robinson noem dit reuse 'adaptive challenges' (2003:15). McNeal (2003:5) praat van 'n bepaalde wêreldbeskouing wat tot ' $n$ einde gekom het. In pre-moderne en moderne eras was dit voldoende om probleme op meganiese wyse op te los, in die huidige era is dit nie meer moontlik nie (Malphurs 1993:94; sien ook Robinson 2008:17 verv).

\section{Soeke na antwoorde}

In die soeke na antwoorde is daar'n konstruktiewe teologiese gesprek aan die ontluik tussen missionale teoloë soos Alan 
Hirsch, Michael Frost, Tim Catchim en ander. So het die term missionaal op die voorgrond getree sedert 'n klein groepie missionale teoloë in 1998 'n publikasie die lig laat sien het: Missional Church: A Vision for the sending of the Church in North America:

The term immediately became a cliché that today means everything or nothing. Its original sense, focusing on the essential purpose and character of the church as the called and sent instrument of God's mission in the world, has been recognised and enriched by the work of such pioneer planters of PostChristendom Western indigenous churches (my term) as the authors of this book. (Guder 2012:xv [foreword in Hirsch \& Catchim])

Daarom is dit noodsaaklik dat Hirsch se definisie van missionaal deurentyd in gedagte gehou word:

Missional church is a church that defines itself, and organises its life around it's real purpose as an agent of God's mission to the world. In other words, the church's true and authentic organizing principle is mission. When the church is in mission, it is true church. The church itself not only is a product of that mission, but is obligated and destined to extend it by whatever means possible. The mission of God flows directly through every believer and every community of faith that adheres to Jesus. To obstruct this is to block God's purposes in and through his people. (Hirsch \& Altclass 2009:212)

Hirsch en Catchim se missionale ekklesiologie is geskoei op die apostoliese strategie van die Nuwe Testament. Aanvanklik het die Christelike apostolaat daarop gefokus om gemeenskappe te roep en te vorm om die getuienis oor die persoon en werk van Jesus Christus voort te sit en om op hulle beurt ook weer sulke geloofsgemeenskappe te vorm. Om hierdie strategie vir die hedendaagse kerk te herwin, moet die funksies van Efesiërs 4: apostel, profeet, evangelis, herwin word. Hierdie vertrekpunt gaan gepaard met kritiek op die reduksie van die vyf wesenlike funksies van Efesiërs 4 tot slegs twee: herder en leraar. Dit het missionale kerkwees in die Weste lam gelê. Guder sien die klerikalisme wat uit hierdie reduksionisme voortgevloei het as 'one of the major and most daunting challenges that the Western Christian movement faces as it moves out of the protections of established Christendom' (2012:xiv).

Die herwinning van die apostoliese funksie is van kardinale belang vir missionale ekklesiologie. Callahan het in 1990 reeds daarop gewys dat '(T) the day of the professional minister is over. The day of the missionary pastor has come'. Die herwinning van die apostoliese funksie is van die grootste belang aangesien dit voorwaarde vir kerkwees is (Nel 1994:28).

Die missionale ekklesiologie van Hirsch en Catchim gaan uit en uit oor die herwinning van die kerk se apostoliese funksie. Dit is 'n ekklesiologie wat hulle vanuit verskeie perspektiewe beredeneer: eksegeties-teologies sowel as organisatoriessosiologies. Om die apostolisiteit te beliggaam gebruik hulle verskillende insigte uit die wêreld van organisatoriese gedrag en leierskap in die Westerse kulture. Vir Guder (2012:xvii) is dit'n uitstekende voorbeeld van kontekstualisering (sien ook Rouse \& Van Gelder 2008:37).
Niemandt (2013:20) sien die gesprek oor missionale gemeentes as ' $n$ 'missionale Renaissance'. In hierdie proses is dit belangrik om te ontdek dat God op die mees onverwagte plekke reeds aan die werk is (Niemandt 2013:26). 'n Kerk wat dit ontdek, skoei hulleself op die voorbeeld van God se beweging na die mensdom toe in Jesus Christus. Christus se menswording getuig van God se solidariteit met en sy omgee vir die wêreld. Inkarnasie veronderstel nie slegs dat God in Jesus Christus mens geword het nie, maar ook dat Hy deel geword het van die ekonomiese, politieke, en godsdienstige realiteit asook van die sosiale grense van sy tyd. Dit is daarom 'n oproep aan gelowiges om op dieselfde wyse as God om te gee vir God se wêreld. Die begrip inkarnasie gee ' $n$ totaal ander inhoud aan die missionale gesprek. Ons leer God primêr ken in die aardse, alledaagse verhale wat oorvertel en in die Bybel opgeteken is as gebeure wat op 'n spesifieke tyd en plek afgespeel het. Dit is die Drie-Enige God self aan die werk: die Vader het die Seun in die alledaagse werklikheid van 'n Palestina van om en by 2000 jaar gelede, ingestuur. Dit is ook die Vader en Seun wat die Gees in die alledaagse werklikheid van ons hedendaagse bestaan instuur om die Goeie Nuus waar te maak in die lewe van gewone mense en gemeenskappe. Inkarnasie beteken dat volgelingskap praktiese neerslag vind in gewoon alledaagse aspekte. Die menswording van Jesus Christus het gevolge vir elke mens en word herhaal in elke mens - daarom sê Paulus dat hy vir die Jode soos ' $n$ Jood geword het en vir die heidene soos 'n heiden.

\section{Inkarnerende sending}

Volgens Markus 3:13-19 het Jesus twaalf, 'wat Hy apostels genoem het, aangestel om by Hom te bly sodat Hy hulle kon uitstuur om te preek. Hulle het ook die mag ontvang om duiwels uit te dryf'. Vroeër in Jesus se bediening, toe die twaalf hulleself slegs gesien het as dissipels (leerlinge), het die evangelis reeds hulle uiteindelike doel as gestuurdes geskets (as getuies van alles wat God in Jesus gedoen het). Hiervoor moes die twaalf by Hom bly en alles leer wat Hy hulle geleer het. Dit was die essensie van wat hulle moes gaan verkondig. Hulle moes ook eers die krag ontvang wat alleen Hy kon gee om die magte van hierdie wêreld te kon weerstaan in sy Naam. Soos wat hulle die verlossingswerk van Jesus verkondig, moes hulle dit doen soos hulle dit gehoor het toe hulle saam met Hom geleef en by Hom geleer het. Hulle het dus die hoe van Jesus se sending geleer soos wat hulle die wat en die hoekom van die Goeie Nuus geleer het.'The emphasis upon incarnational mission is integrative in a very distinctive way' (Guder 1999:5). Hierdie twee wesenlike dimensies van die evangelie moet voortdurend met mekaar geïntegreerd gehou word, naamlik die verlossende gebeure van Jesus se dood en opstanding tesame met die voorbereiding van sy sendelinggemeenskap om daardie getuienis voort te dra. Dit sal verseker dat die 'wêreld' (Joh 3:16) wat God liefhet, inderdaad daardie goeie nuus hoor. Daarvoor moet die fokus altyd wees om dissipels te maak met die oog op apostelskap (Mead 1994:43). 
Handelinge begin deur te berig oor Jesus se persoonlike ontmoeting met sy dissipels voor sy hemelvaart. Die opgestane Here deel sy volgelinge hulle nuwe taak mee: 'Maar julle sal krag ontvang wanneer die Heilige Gees oor julle kom, en julle sal my getuies wees in Jerusalem sowel as in die hele Judea en in Samaria en tot in die uithoeke van die wêreld' (Hand 1:5). Vir die missionale teologie van LukasHandelinge is getuie-wees die deurslaggewende term. Getuie-wees beteken: alles wat die Christelike gemeenskap is, doen en sê moet blyke wees van getroue gehoorsaamheid aan die Heer van die kerk en daarmee saam ook uitdrukking van die Here se liefde vir die wêreld.

Guder (1999:6) sien die Nuwe Testament as 'n deurlopende onderrig van hoe die kerk as 'n missionale gemeenskap getrou kan bly aan sy roeping. Die begrip getuie integreer die wie, wat en hoe van die Christensending. Die Christen as individu word gedefinieer as Christus se getuie; die hele Christengemeenskap word gedefinieer as 'n getuigende gemeenskap; die kerk se impak op die wêreld waarin die kerk gestuur word, is die kerk se waarneembare getuienis; al die kerk se aktiwiteite is op een of ander wyse uitdrukking van hierdie getuienis. God se Gees wat op verborge en genadige maniere werk bemagtig die menslike en feilbare getuies om die instrumente te wees waardeur die wêreld die goeie nuus hoor en uitgenooi word om volgelinge van Jesus te word. Die doel van inkarnerende getuienis is 'sodat die genade van God steedsmeer mense kan bereik. Dan word die dankgebede ook meer, en God ontvang die eer' (2 Kor 4:15).

\section{Inkarnerende getuienis}

Inkarnerende getuienis impliseer ondergeskiktheid aan alles wat Christus verteenwoordig. Ten spyte van die struikelblokke watdie sondige menslike natuur meebring, bly Jesus se menswees die duidelike riglyn van hoe en wat God wil dat sy mense sal wees:

The Christian's life in communion with Christ, which for Barth forms the very heart of our calling and identity as witnesses, means that we belong to Jesus, we are constantly confronted and converted by his love, and we discover the very content of our life in serving him. (Guder 1999:16)

Inkarnerende getuienis is dus getuienis van die volledige doel en skopus van God se handelinge in Christus. Hierdie uitgangspunt moet verstaan word teen die agtergrond van die reduksionisme wat hand aan hand gaan met 'n digotomie wat endemies blyk te wees aan Westerse Christendom: dit is dat persoonlike verlossing los gesien word van die missionale doel waarvoor God mense roep en verlos. 'The mission-benefits dichotomy (which I explore in Be My Witnesses) is diametrically opposed to incarnationale witness' (Guder 1999:17). In die lewe en werk van die missionale gemeenskap moet die volheid van Jesus se goeie nuus bekendgemaak word. Dit is die evangelie wat gelei het tot die heling van die skepping, die vestiging van geregtigheid, en die ontbloting van sisteme van verdrukking wat in stryd met God se bepalings is. Getuienis van hierdie evangelie is die kerk se roeping. Dit beteken dat die evangelie altyd die roeping tot dissipelskap is wat op apostolaat uitloop.
Daar is ook ' $n$ ander vorm van reduksionisme te bespeur, veral by die hoofstroomkerke. Dit is dat lidmate kan deelneem aan programme wat uit die evangelie voortspruit, sonder dat hulle die goedheid van die evangelie self ervaar. Dit gebeur wanneer die koninkryk van God verstaan word as resultaat van uitsluitlik menslike pogings, en nie as resultaat van die missio Dei nie. Die wisselwerking tussen God en mens moet konsekwent gehandhaaf word.

\section{'n Inkarnerende geloofsgemeenskap}

Getuienis oor Jesus word geïnkarneer soos wat die gemeente gevorm word as ' $\mathrm{n}$ missionale geloofsgemeenskap (vgl. Van der Merwe 2015:25). Jesus se model met die oog op die missionale getuienis van sy kerk is om dissipels te maak wat apostels word. So word missionale geloofsgemeenskappe gevorm. Die evangelie moet vertel en uitgeleef word; soos wat die evangelie vertel en uitgeleef word deur 'n spesifieke geloofsgemeenskap sit daardie geloofsgemeenskap God se reddende werk voort. Pinkster is immers die gevolg en implementering van Paasfees. Wat God gedoen het in Jesus se opstanding en bevestig het by Jesus se hemelvaart, word nou bekend gemaak in die hele wêreld deur Jesus se volgelinge:

It is of the essence of the matter that Jesus was not concerned to leave as the fruit of his work a precise verbatim record of everything he said and did, but that he was concerned to create a community which would be bound to him in love and obedience, learn discipleship even in the midst of sin and error, and be his witnesses among all people. (Guder 1999:21)

Jesus het sy dissipels gekies en voorberei om die kern te wees van sy nuwe missionale volk wat Hy sou uitstuur as sy getuies. So het Hy die verlossingsverhaal wat begin met Abraham, gekontinueer. God het Abraham en sy nageslag geseën met die oog daarop om 'n seën vir die nasies te wees (Gen 12:1-3; 22:15-18; 26:4-5). Die keuse van 12 dissipels (Mark 3:13 verv) is 'n doelbewuste voortsetting van die verhaal van Israel (Guder 1999:22).

Die sentrale plek van 'n geloofsgemeenskap in hierdie verhaal impliseer dat die evangelie 'altyd beliggaam was.' Die Woord moet altyd weer vlees word, beliggaam word in 'n geloofsgemeenskap. Die evangelie kan nooit volledig vasgevang word in preposisies, geloofsbelydenisse of teologiese sisteme, hoe belangrik dit ook mag wees nie. Die evangelie woon in en vorm die mense wat as getuies van die evangelie geroep is. Die boodskap is dus onlosmaaklik verbonde aan die boodskapper. So het die vroeë kerk in Jerusalem geleef op ' $n$ wyse wat die hele volk goedgesind was (Hand 2:47). Die getuienis wat deur die Christelike geloofsgemeenskap geleef word, word so geleef omdat daardie geloofsgemeenskap getuie is, sigbaar en hoorbaar, gegee in en aan die wêreld, sodat die evangelie al verder gehoor én gesien salword. Dieinkarnerendegetuienis van diegeloofgemeenskap is egter nie 'sondeloos' nie, maar die beliggaaming van genade soos wat dit gestalte kry in berou, bekering en vergifnis:

Like the individual Christian, the incarnational community lives and testifies as a people who are simul justus et pecator (Martin Luther). What the world should experience in the church is not 
perfect Christians, but honest Christians whose lifes enflesh the real possibility of new life, a new creation, living hope, and confidence that 'the one who began a good work among you will bring it to completion by the day of Jesus Christ (Phil 1:6)' (Guder 1999:23)

Om 'n perfeksionistiese kerkbegrip te voorkom, moet die inkarnerende geloofsgemeenskap met omsigtigheid gedefinieer word. Realisme oor die kerk se menslike broosheid mag nooit die Gees se krag om God se volk te transformeer oorskadu nie. Die inkarnerende karakter van die kerk word immers nie gegrond in perfeksionisme nie, maar in die kerk se onderwerping aan Christus. Die identiteit van die kerk word gedefinieer deur haar verhouding met Jesus Christus. Hulle verhouding met Jesus was immers die rede waarom die Jesus-volgelinge aanvanklik die naam 'Christene' (Hand 11:26) gekry het. Die kerk se selfverstaan as inkarnerende geloofsgemeenskap moet gefokus bly op die kerk se doel soos bepaal deur die Heer van die kerk. Soos wat die kerk in die Weste op grond van hierdie selfverstaan poog om 'n missionale teologie te ontwikkel, kry die kerk met veral twee uitdagings te doen.

Eerstens is inkarnerende apostolaat 'n uitdaging vir die institusionele kerk van die Christenheid. As dit waar is dat Christus die roeping van die kerk definieer, en as die geroepe geloofsgemeenskap die goeie nuus moet inkarneer kan nóg die instituut se oorlewing nóg die instandhouding van die instituut, prioriteit wees. Die instituut is nie die uiteindelike en bedoelde resultaat van God se genade nie. Christus het nie gesterf om Christene te red nie, of om 'n passiewe gemeenskap van geredde mense te vorm nie, maar om God se redding na die wêreld toe te bring. Die vorming van die kerk en die verlossing van die kerk se lede is slegs die eerste vrugte van God se wens vir die hele skepping. Die apostolaat mag daarom nie gereduseer word tot institusionele instandhouding of oorlewing nie. Die vorming en voortsetting van institute is egter 'n historiese verskynsel van hoe groepe hulleself onvermydelik orden. Die vorming en ordening van God se volk is by sowel Israel as die kerk noodwendig ook 'n institusionele proses. Hirsch is oortuig dat strukture noodsaaklik is, 'but they must be simple, reproducible and internal rather than external' (2006:186). Die probleem lê daarom nie by die dat van institute nie, maar by die hoe:

\footnotetext{
If this were not so, then the calling and sending of God's people would be a docetic, non-historical 'spiritual' process with little relevance to the world God loves. The problem is not that the church is institutional but how it is institutional. From the beginning of his ministry, Jesus challenged the institutional forms of God's elect people because in many ways, they become a betrayal of God's mission. (Guder 1999:25)
}

Jesus se kritiek op die religieuse leiers van sy tyd lê die verskeidenheid bloot waarop die institute van toe en nou die mandaat tot inkarnasie kan reduseer en verwring. Jesus se boodskap was in hierdie verband konstant 'n oproep tot bekering. Die institusionele kerk het blykbaar 'n subtiele maar tegelyk kragtige belang daarby om die evangelie beheerbaar te maak (Joubert 2009:50). As verdedigers en begunstigdes van die instituut, word die kerk egter deur die mandaat van inkarnerende apostolaat uitgedaag om die manier waarop die kerk funksioneer, krities te evalueer. Die vraag waarmee die inkarnerende verstaan van apostolaat die kerk konfronteer is: is die institusie 'n beliggaming van die goeie nuus? Weerspieël die wyse waarop die kerk as organisasie lewe, werk, geld bestee en besluite neem, beide die karakter en die doel wat God vir die mensdom het?

Tweedens daag inkarnerende apostolaat individualisme uit wat so eie is aan die Westerse kultuur. As die evangelie geïnkarneer word in en deur 'n geloofsgemeenskap, moet die individuele Christen gedefinieer en verstaan word as deel van die geloofsgemeenskap. Die individuele Christen is konstitusioneel deel van 'n organiese geheel wat lewe en funksioneer wanneer al die onderdele van die geheel hulle wedersydse interafhanklikheid beoefen. Hierdie interafhanklikheid doen nie afbreuk aan die besondere evangelie-belewenis van die individuele Christen nie. Die ervaring van die individuele Christen bly altyd gegrond in God se voorafgaande handeling deur die geloofsgemeenskap en dit moet daardie gemeenskap op sy beurt ook verryk. Individue glo omdat God in die geloofsgemeenskap werk. Verder weef die Heilige Gees elke gelowige se storie van geloof in die storie en getuienis van die hele geloofsgemeenskap in.

Die uitdaging aan die kerk is: hoe kan die inkarnerende geloofsgemeenskap so gevorm word dat hulle nie op religieuse perfeksionisme aanspraak maak nie maar voortdurend lewe in volgehoue onderwerping aan hulle Here en individualisme op radikale wyse oorkom deur die persoonlike en korporatiewe dimensies van hulle geloof aan mekaar te verbind?

Gelowiges word geroep om Jesus soos die 12 dissipels te volg en om die apostoliese opdrag voort te sit. In die wêreld van die Nuwe Testament het ' $n$ dissipel homself onderwerp aan 'n leermeester in 'n intieme, allesomvattende verhouding van leer, imiteer en volg (Bell 2005:127; Watson 1983:19-31). Die intieme verhouding van dissipelskap vorm die basis van inkarnerende apostolaat. Beide getuienis en impak as getuies (martyroi en martyria) word gevorm deur Jesus Christus. Die werk wat Hy begin met en deur die aanvanklike dissipels word dus voortgesit in en deur die versamelde geloofsgemeenskap van nou. Dit is ook die kern van die apostolisiteit van die kerk. Die verhouding wat die eerste dissipels met Jesus gehad het word voortgesit in elke spesifieke geloofsgemeenskap se eie verhouding met hulle Heer. Hierdie intimiteit vorm ook die hart van die Christelike erediens, veral die Nagmaal as belewenis van Christus se teenwoordigheid.

\section{Herstel die DNS}

Vir Hirsch en Catchim (2012:xx verv) is die rede waarom die hoofstroomkerke steeds sukkel om God se missionale opdrag uit te voer, geleë in 'n onvermoë om die voorskrifte volgens Efesiërs 4 te implementeer. Hulle beskou Efesiërs 4:1-16 as die noodsaaklike boustene vir missionale bediening. Hulle is 
oortuig dat waardering en aanwending van Efesiërs 4 enorme energie sal loslaat, wat die tans dormante potensiaal in die kerk sal ontsluit. Elke missionale beweging in die wêreld wat 'n noemenswaardige resultaat gehad het, is gebou op die vyfvoudige bediening van Efesiërs 4. Die herontdekking en die herinstelling van die ekklesiologie wat Efesiërs 4 voorhou, hou ook geweldige potensiaal in vir ons eie situasie. Dit is 'n ekklesiologie wat op die vyfvoudige bediening van Efesiërs 4 (APEHL: apostel, profeet, evangelis, herder en leraar = DNS van die kerk) gebou is (Hirsch \& Catchim 2012:8):

- Die apostel is getaak met sowel die algehele lewenskrag (vigour), as die daadwerklike uitbreiding van die Christendom as geheel. Dit word direk gedoen deur sendingwerk en kerkplanting. Soos wat die naam suggereer is dit die egte missionale bediening van gestuur wees (missio), ingeskryf in apostello [die gestuurde een].

- Die profeet is geroep om getrouheid aan God onder die mense van God in stand te hou. In wese is die profete die bewakers van die verbondsverhouding.

- Die evangelis is die werwer. Dis die 'aansteeklike persoon', iemand wat in staat is om mense vir die beweging te werf en in te skakel deur die evangelie oor te dra.

- Die herder is geroep om geestelike ontwikkeling te voed, die gemeenskap se gesondheid te onderhou, en om 'n liefdevolle gemeenskap tussen die mense van God te kweek.

- Die leraar bemiddel wysheid en begrip. Die filosofiese tipe bring 'n oorkoepelende uitgebreide verstaan van die openbaring wat aan die kerk bemaak is (Hirsch \& Catchim 2012:8).

$\mathrm{Al}$ vyf hierdie bedieninge is noodsaaklik om missionale kerk te wees.

\section{'n Brief aan almal}

Daar kan baie afgelei word van die aard van ' $n$ brief as dit bekend is aan wie die brief geskryf is (Hirsch \& Catchim 2012:10). Die brief aan die Efesiërs is geadresseer aan gewone mense wat deel was van die talle huiskerke dwarsoor die stad Efese, mans, vroue, slawe, verskillende rasse, klasse en sosio-ekonomiese status. Efesiërs is 'n brief vir die kerk oor die kerk en moet so gelees word. Verder is dit 'n generiese brief, bedoel vir wyer gebruik onder die verskillende Nuwe Testamentiese kerke, waaronder ook Efese. Die Efesiërbrief is nie 'n kontekstuele dokument nie. Galasiërs en 2 Korintiërs is gerig aan spesifieke gemeenskappe wat met spesifieke probleme geworstel het. Efesiërs het universele betekenis wat verder strek as lokale probleme in 'n gemeente (verg Hirsch \& Catchim 2012:10). Die universele aard van die ekklesiologie in Efesiërs, herposisioneer ons om die Efesiërs te sien as 'n soort konstitusionele dokument vir kerkwees met verse 11 en 12 as die wyse om die konstitusie operasioneel te maak (verg Hirsch \& Catchim 2012:10).

Die APEHL van Efesiërs 4 voorsien ook die nodige taal om 'n volledige woordeskat om die kerk te organiseer. Sodoende kan die verstaan van die kerk se wesenstaak/roeping hervorm word. In plaas daarvan om die kerk slegs te sien as 'n verlengstuk van die teologiese opleiding (Leraar), of as geestelike voedingstasie (Herder), moet kerkwees verstaan word as beliggaaming van Christus se totale bediening. Indien volhard word met die bestaande standaard raamwerk van leraar en herder in pogings tot kerk-planting, sal die nuwe 'plant' slegs ook net eredienste hou en Bybelstudies aanbied.

'n Breër APEHL verstaan en woordeskat sal ook insig bring in die ander funksies van die kerk. Wanneer die teks self ontleed word, kan drie 'bewegings' binne die oorkoepelende eenheid van Efesiërs 4:1-16 onderskei word: Eenheid in verse 1-6, diversiteit/APEHL in verse 7-11, en volwassenheid in verse 12-16 (verg Hirsch \& Catchim 2012:13-15).

\section{Eenheid in die een God: Verse 1-6}

Die teks aan die begin van Efesiërs 4 vloei voort uit 'n gebed vir die kerk in Efesiërs 3:14-21 (Hirsch \& Catchim 2012:13 verv). Dit is 'n gebed vir hulle kennis van God in Christus asook dat hulle mag opgroei om die volheid van Christus in die wêreld te wees. Direk na die gebed volg 'n beroep om deurlopend te leef met 'n besef van wie God is en wat Hy in Christus gedoen het.

Efesiërs 4 is die 'skarnier' deel van die brief waar daar van teologie na praxis beweeg word. En soos enige goeie inleiding tot 'n konstitusie, word die kern teologiese noodsaaklikhede hier saamgevat in sewe teologiese stellings waarmee verwys word na:

- God

- geloof

- $\quad$ en die kerk se eenheid (Hirsch \& Catchim 2012:13).

\section{Eenheid}

Soos vele ander aspekte in die Efesiërbrief is die sewe 'ene' (een liggaam, een Gees, een hoop, een Here, een geloof, een doop, een God en Vader van almal), almal universele waarhede. Dit verskaf die teologiese koördinate om eenheid in die ontluikende en toenemend diverse beweging te behou. So word die teologiese integriteit van die kerk gehandhaaf en daarmee ook die grense vir die regte leer getrek (verg Hirsch \& Catchim 2012:13).

\section{Diversiteit}

Nadat die basis vir kerklike eenheid gelê is, beweeg Efesiërs 4 dadelik na die Christus-toegedeelde aard van die bediening van die ekklesia (Ef 4:7-11). Nadat daar oor die hemelvaart gehandel is sê die outeur dat Jesus sekere 'gawes' (bedieninge, roepings, of opdragte) aan die kerk 'gegee het' (aoristus indikatief), en dit verder uitgedeel het soos wat Hy dit goedgedink het. Hierdie gawes is duidelik en ondubbelsinnig benoem as die APEHL. Hierdie gawes is Christologies en verteenwoordig die konstitusionele bediening van die kerk (verg Hirsch \& Catchim 2012:14). 


\section{Volwasse in Christus}

Hoewel dit ' $n$ valse breuk is om vers 12 van vers 11 te skei, kan daar tog 'n skuif in die argument onderskei word. Dit is 'n skuif vanaf die voorskrywing van die APEHL in vers 11 na 'n beskrywing van die verwagte uitkomste daarvan in vers 12. Dit gee insig in die rede waarom die APEHL in die eerste plek gegee is. Dit is gegee sodat die liggaam van Christus kan groei en volwasse word (beliggaming), die eenheid wat in verse 1-6 beskryf is, uitgeleef kan word, om werklike begrip te kry dat Christene nie wispelturig sal wees wat oorgegee aan teologiese illusies lewe nie en ook om hulle organiese heelheid in Christus en mekaar te vind, soos wat Jesus hulle bedoel het om te wees (Hirsch \& Catchim 2012:14).

Die logika van Efesiërs 4 is geïntegreerd en teologies gesond. Dit verduidelik dat die kerk se vermoë tot wederkerigheid en volwassenheid gebaseer is op die ortodokse leer maar ook op die kerk se bediening soos uitgedruk in APEHL. 'n Volwasse en gesonde kerk leef sy belydenis uit soos wat die kerk ook in sy belydenis lewe. Indien die inherente logika van die teks geïgnoreer word moet die uitkomste verwag word wat sodanige ignorering noodwendig teweeg gaan bring (Hirsch \& Catchim 2012:15).

Volgens Efesiërs 4 is 'n ten volle funksionerende vyfvoudige APEHL-bediening die Christus-gegewe verdedigingsmeganisme teen dwaalleer en valse leer. Die APEHL as geheel laat die kerk verby 'n teologiese naïwiteit beweeg en anker die kerk in 'n geïntegreerde verstaan van die sentrale boodskap en kern-leerstellings van die kerk. Vreemd genoeg - dit is juis die diversiteit wat in die APEHL vervat is wat die kerk help om tot eenheid in die geloof te kom (Hirsch \& Catchim 2012:16).

Wanneer die teks gewoonweg (induktief) gelees word sonder 'n vooraf teologiese voorveronderstelling (deduktief), is dit nie moeilik om te sien dat die kerk nie kerngesond kan wees sonder die APEHL-bediening nie. Vers 13 sê dit uitdruklik, terwyl die logika van die hele teks dit ook in die oog het. Daar bestaan geen twyfel dat verse 1-6 as gesaghebbend aanvaar word vir die leer van die kerk nie. Dit is duidelik bedoel vir die universele kerk van alle tye en plekke. So ook verse 12-16. Indien die teksgedeeltes aan elke kant van verse 7-11 gesaghebbend en bindend is vir die kerk van alle tye en plekke, kan verse 7-11 nie minder gesaghebbend, bindend en universeel wees nie. Hierdie verse maak trouens grammatikaal en tematies die hart van hierdie skrifgedeelte uit. Dit is eenvoudig nie moontlik om die kerk te wees wat Jesus ons bedoel het om te wees as drie bedieninge (APE) nie volledig deel uitmaak van die $v y f^{\prime}$ 'konstitusionele' bedieninge van die kerk nie (verg Hirsch \& Catchim 2012:16).

Dit het egter gebeur en die tragiese gevolge daarvan word wêreldwyd deur hoofstroomkerke ervaar. En selde indien ooit het die kerk op grond van Efesiërs probeer om dit reg te stel.
Die soort volwassenheid wat Efesiërs 4 bedoel is die kerk se kapasiteit om die missio van Jesus in die wêreld te beliggaam. Wanneer gesê word die APEHL is gegee om die 'heiliges toe te rus' word die woord kataptismo gebruik. Dit kan ook beteken, 'om 'n gebreekte been te spalk'. APEHL help die kerk dus om volwasse te word dat die 'liggaam' kan 'loop' en uiteindelik kan 'staan' teen die magte wat die mensdom 'ont-mens' (Ef 6:10-16) (Hirsch \& Catchim 2012:16).

\section{Die weglating van die APE's}

Die fokus is om die wanbalans reg te stel wat ontstaan het as gevolg van die noodlottige weglating van die A(postel), $\mathrm{P}$ (rofeet) en $\mathrm{E}$ (vangelis). Die gevolg van hierdie weglating was dat alle bedieninge 'ingeforseer' moes word in die formate van $H$ (erder) en $L$ (eraar) (pastor en teoloog). Deur die APE binne die eerste drie eeue van die Christelike geskiedenis uit die kerk se bediening uit te rangeer, en die kerk se bediening daarna slegs te definieer aan die hand van die $\mathrm{H}$ en L (die herder en teoloog), het die kerk effektiewelik iets gedoen wat genoem kan word 'reflektiewe ekwilibrium', dit is om feite en bewyse by voorafbestaande kategorieë te maak pas (Hirsch \& Catchim 2012:17). Guder in Hirsch en Catchim (2012) vind die oorsprong hiervan by Calvyn:

Calvyn bestee baie aandag aan die relevansie van Ef 4:1-16 vir die formasie en strukturering van die kerk. Maar na etlike eeue van Christendom, het hy probleme met Christus se gawes van sommige as apostels, profete en evangeliste. Calvyn argumenteer dan soos volg: 'Hierdie drie funksies is nie in die kerk gevestig as funksies nie, maar dit is slegs gevestig vir daardie tyd waarin die kerk opgerig moes word en daar geen kerk vooraf bestaan het nie'. Hy erken dat daar spesiale geleenthede mag wees waar hierdie ampte weer nodig mag word, maar die APE sal volgens Calvyn, buitengewone ampte/bedieninge bly. Maar, so redeneer Calvyn verder, die $\mathrm{H}$ en $\mathrm{L}$ (die pastors en leraars/teoloë) is ampte waarsonder die kerk glad nie kerk kan wees nie. (bl. 19)

Dit verklaar hoe die tradisionele herder-leraar model die (vals) standaard geword het waarby alle bedieninge gemaak pas is, sodoende het die pastor (herder) en in ' $\mathrm{n}$ mindere mate ook die leraar, die oorkoepelende-alles-insluitende titels geword, terwyl die woord pastor/herder (pomein) slegs 1 keer gevind word (in Ef 4). Die Woord leraar word meer kere in die Nuwe Testament gebruik - 10 keer. En tog is herder en leraar die standaard vir alle bedieninge gemaak (verg Hirsch \& Catchim 2012:20).

\section{Een aoristus}

Wat betref die APEHL is dit belangrik om daarop te let dat die werkwoord vir 'gegee' (edothe) in verse 7 en 11 aoristus indikatiewe is. Dit beteken hierdie gawes is vir eens en vir altyd aan die kerk gegee, met 'n duidelike en steeds geldende betekenis vir die kerk. Wat meer is, is van al vyf APEHL bedieninge word gesê hulle is edothe [gegee]. In die Griekse taal bepaal die werkwoord die objekte waarna dit verwys. Nie een van hierdie vyf bedieninge kan afgeskaal of geïgnoreer word sonder om die legitimiteit, betekenis en lewensvatbaarheid van die ander terselfdertyd te ondermyn nie (verg Hirsch \& Catchim 2012:20). 


\section{Aan elkeen van ons}

Waar die APEHL wel ernstig opgeneem word, word dit gesien as slegs van toepassing op die kerkleierskap (verg Hirsch and Catchim 2012:21-22). So word gemeen dat Jesus sommige in die liggaam toegerus het om ander op te lei vir bediening. Met die eerste oogopslag klink dit reg. Hierdie interpretasie van die teks is egter die newe-produk van die institusionele maniere waarop die kerk oor die jare georganiseer is en verstaan dit nie die ekklesia van die Nuwe Testament as ' $n$ beweging nie.

Dit kan reggestel word deur die teks van vers 7 af te lees in plaas van vers 11 af. Vers 7 lees: 'Aan elkeen van ons (Grieks hekasto) is 'n genadegawe gegee volgens die mate waarin Christus die gawes uitgedeel het'. Hekasto beteken letterlik, aan elke iedere een. Die outeur se bedoeling was dat sy lesers letterlik sou verstaan, aan elkeen, dit is, elke gelowige wat hierdie woorde lees en hoor, in die outeur sowel as in ons tyd. Hierdie gawes is nie aan ' $n$ paar van die elite gegee tot voordeel van die baie nie, maar dit is aan almal gegee tot voordeel van almal; dit is die gelowiges wat die gelowiges moet toerus.

Hou in gedagte dat hierdie brief geskryf is aan die huiskerke, om hardop in elke huiskerk gelees te word. So kon die versamelde ekklesia in Efese en nie slegs die leiers nie, hoor wat die apostel leer. Die brief is gerig aan al God se mense van oor al die rassegrense, sosiale grense, ekonomiese grense, en geslagsspektrum. Die APEHL-tipologie sluit dus alles in. Dit is 'n groot paradigmskuif wat ons na die hart neem van wat dit beteken dat die kerk missionale beweging moet wees (verg Hirsch \& Catchim 2012:20-22).

\section{Christus se bediening in en deur sy liggaam}

Vers 11 teken die bediening van Christus, soos dit uitgedruk word in en deur die liggaam van Christus as Apostel, Profeet, Evangelis, Herder en Leraar (verg Hirsch \& Catchim 2012:22-23). Omdat die kerk liggaam van Christus is, moet dit al die dimensies van Christus se bediening weerspieël. Elke (APEHL) gawe is tegelyk ' $n$ uitnodiging én 'n voorsiening van die middele om deel te neem aan die werk van Jesus. ' $n$ Tweevoudige bediening kan nie die allesomvattende werk van Christus in hierdie wêreld reflekteer nie. Die APEHL is gewortel in en terselfdertyd brei dit ook die oorspronklike bediening van Jesus uit (Hirsch \& Catchim 2012:23).

Efesiërs 4 gaan oor roeping. Efesiërs 4:1: ‘... laat julle lewenswandel in ooreenstemming wees met die roeping wat julle van God ontvang het' (kalesis). In die Griekse teks word kalesis twee keer gebruik: 'die roeping waarmee Hy julle geroep het' (Hirsch \& Catchim 2012:25). Die opvallende hier is die wyse waarop werkwoorde in vers 11 gebruik word. In plaas daarvan om die aktiwiteite wat afsonderlik en apart van die individu bestaan te lys, word die 'wees' met die 'doen' verbind. Die 'taak' en die 'persoon' is met ander woorde dieselfde. Dit is ' $\mathrm{n}$ kwessie van roepingsidentiteit (Hirsch \& Catchim 2012:25). Deur APEHL is die gelowige se identiteit en roeping in Christus gewortel. Indien aanvaar word dat APEHL die struktuur is wat die Here self gegee het, sal dit nie slegs moontlikhede open in terme van onbenutte menslike kapitaal nie; dit sal die kerk ook posisioneer om weereens verryk te word met die volle spektrum van die kollektiewe DNS wat Jesus in sy volgelinge geplaas het. Die APEHL is nie slegs Bybels nie, dit bied ook alles wat die kerk nodig het om sy roeping en opdrag uit te voer ten spyte van al die uitdagings van die 21ste eeu. Om die APEHL te ontsluit kan vergelyk word met die krag wat losgelaat word by kernfusie (Hirsch \& Catchim 2012:26).

\section{Erkenning Mededingende belange}

Die outeur verklaar dat hy geen finansiële of persoonlike verbintenis het met enige party wat hom nadelig kon beïnvloed het in die skryf van hierdie artikel nie.

\section{Literatuurvewysings}

Bell, R., 2005, Velvet Elvis: Repainting the Christain faith, HarperCollins, New York.

Bosch, D.J., 1993, Transforming mission. Paradigm shifts in theology of mission, Orbis Books, Maryknoll, NY.

Callahan, K.L., 1990, Effective church leadership: Building on the twelve keys, Harper, San Francisco, New York.

Guder, D.L.,1999, The incarnation and the church's witness, Trinity Press International, Harrisburg, PA.

Hirsch, A., 2006, The forgotten ways: Reactivating the missional church, Brazos Press, Grand Rapids, MI.

Hirsch, A. \& Altclass, D., 2009, The forgotten ways handbook, BrazosPress, Grand Rapids, MI

Hirsch, A.\& Catchim, T., 2012, The Permanent revolution: Apostolic Imagination and Practice for the 21st Century Church, Jossey-Bass, San Francisco, CA.

Joubert, S., 2009, Jesus ' $n$ radikale sprong, Christelike uitgewersmaatskappy, Vereeniging.

Kirk, J.A., 2000, What is mission?: Theological explorations, Fortress Press, Minneapolis, MN.

Malphurs, A., 1993, Pouring new wine into old wineskins: How to change a church without distroying it, Baker Books, Grand Rapits, MI.

Mead, L.B., 1994, Transforming Congregations for the future, The Alban Institute, Inc, Bethesda, MD.

McNeal, R., 2003, The present future, six tough questions fot the Church, Jossey Bass, San Francisco, CA.

Nel, M., 1994, Gemeentebou, Orion Uitgewers, Halfway House, Johannesburg.

Niemandt, N., 2007, Nuwe drome vir nuwe werklikhede, Lux Verbi. BM, Wellington.

Niemandt, N., 2013, Nuwe leiers vir nuwe werklikhede, Christelike Uitgewersmaatskappy, Vereeniging.

Peterson, C.M., 2013, Who is the Church? An ecclesiology for the twenty-first century, Fortress Press, Minneapolis, MN.

Robinson, A., 2003, Transforming congregational culture, William B. Eerdmans, Grand Rapids, MI.

Robinson, A., 2008, Changing the conversation: A third way for congregations, William B. Eerdmans, Grand Rapids, MI.

Rouse, R., \& van Gelder, C., 2008, A Field guide for the missional congregration, Augsburg Fortress, Minneapolis.

Tyra, G., 2013, A missional orthodoxy: Theology and ministry in a post-Christian context, IVP Academic, Downers Grove, IL.

Van der Merwe, J.C., 2015, 'Die inkarnering van die missio Dei as praktykmodel vir die Nederduitsch Hervormde Kerk van Afrika', HTS Teologiese studies/Theological Studies 71(3), Art.\#3066, 1-16. https://doi.org/10.4102/htsv71i3.3066

Van Gelder, C., 2007, 'Missiology and the missional church in context', in C. van Gelder (ed.), The missional church in context: Helping congregations develop contextual ministry, pp 12-43, William B. Eerdmans, Grand Rapids, MI.

Ward, P., 2002, Liquid church: A bold vision of how to be God's people in worship and mission - A flexible, fluid way of being church, Hendrickson Publishers, Peabody, MA.

Watson, D., 1983, Discipleship, Hodder \& Stoughton, London.

Wright, C.J.H., 2006, The mission of God. Unlocking the Bible's grand narrative, IVP Academic, Downers Grove, IN. 